"Automatic exchange of tax information: initiation, implementation and guidelines in Bulgarian context"

AUTHORS

ARTICLE INFO

DO

RELEASED ON

RECEIVED ON

ACCEPTED ON

LICENSE

JOURNAL

ISSN PRINT

ISSN ONLINE

PUBLISHER

FOUNDER
Atanaska Filipova-Slancheva

Atanaska Filipova-Slancheva (2017). Automatic exchange of tax information: initiation, implementation and guidelines in Bulgarian context. Problems and Perspectives in Management, 15(2-3), 509-516. doi:10.21511/ppm.15(si).2017.04

http://dx.doi.org/10.21511/ppm.15(si).2017.04

Wednesday, 27 September 2017

Tuesday, 18 April 2017

Friday, 05 May 2017

\section{(c) EY-No}

This work is licensed under a Creative Commons Attribution-NonCommercial 4.0 International License

"Problems and Perspectives in Management"

1727-7051

$1810-5467$

LLC "Consulting Publishing Company "Business Perspectives"

LLC "Consulting Publishing Company "Business Perspectives"
NUMBER OF REFERENCES

26
NUMBER OF FIGURES

0
NUMBER OF TABLES

0

(C) The author(s) 2022. This publication is an open access article. 


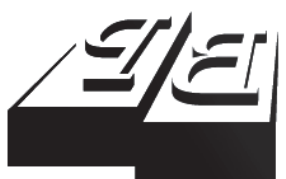

BUSINESS PERSPECTIVES

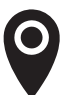

LLC "CPC "Business Perspectives" Hryhorii Skovoroda lane, 10, Sumy, 40022, Ukraine

www.businessperspectives.org

Received on: $18^{\text {th }}$ of April, 2017 Accepted on: $5^{\text {th }}$ of May, 2017

C Atanaska Filipova-Slancheva, 2017

Atanaska Filipova-Slancheva, Dr., Associate Professor, Financial and Accounting Faculty, University of National and World Economy, Bulgaria.

\section{(ㄷ)(1) $(8)$}

This is an Open Access article, distributed under the terms of the Creative Commons Attribution-NonCommercial 4.0 International license, which permits re-use, distribution, and reproduction, provided the materials aren't used for commercial purposes and the original work is properly cited.

\section{AUTOMATIC EXCHANGE OF TAX INFORMATION : INITIATION, IMPLEMENTATION AND GUIDELINES IN BULGARIAN CONTEXT}

\begin{abstract}
The paper aims to introduce and clarify automatic exchange of tax information as a global and European Union initiative in order to curb tax evasion via cross-border tax avoidance, along with aggressive tax competition. It investigates the role of Organization for Economic Cooperation and Development (OECD) which developed Common Reporting Standard (CRS) and endorsed it in 2014. CRS is a framework for automatic exchange of tax information with the purpose to promote cooperation among various jurisdictions. For EU Member States, CRS is transposed by the amended EU Directive on Administrative Cooperation (DAC2). Bulgaria as a member state has transposed the Directive in the national law.

This study examined automatic exchange of tax information (AETI) from Bulgarian perspective - historic development, legal framework, responsible and competent authorities and application of DAC2 and expectations for newly approved DAC3.

In the study, Bulgarian financial institutions (banks) are examined, implementation status and how the challenge of AETI, including client information and data protection, are addressed. Primary data for banks are collected from publicly available sources (website of the respective bank), as company websites of top 5 Bulgarian banks were examined for information related to automatic exchange of financial information/tax information.
\end{abstract}

Results show that major Bulgarian banks, within First Group in terms of assets, are initiating the process, internal due diligence and preparation for the new reporting requirements.

General conclusion is that currently there are some critical issues to be addressed, new DAC3 might introduce higher challenges, as practical guidance is the solution.

Keywords automatic exchange, tax information, Bulgaria, banks

JEL Classification M41, M48, M49, H20, H25, H26

\section{INTRODUCTION}

As an aftermath of the financial crisis of 2007-2008 and in the environment of budget deficits and eroding budget revenues, authorities have initiated a global approach for addressing tax avoidance. Having in mind the fact that individuals or entities may hold assets in other jurisdictions, resis dent countries' authorities should have information about these foreign holdings. Information among respective authorities may be exchanged in the following ways: "upon request", spontaneously, or automatically (Knobel \& Meinzer, 2014). Traditionally, exchange of information was based on "upon request" method, based on bilateral agreements (tax treaties for avoiding double taxation, as well as tax information exchange agreements). A third legal basis for information exchange is the Council of Europe/OECD Multilateral Convention on Mutual Administrative Assistance in Tax Matters. 
In February 2014, the G20 Finance Ministers and Central Bank Governors endorsed the global standard for automatic exchange of tax information, which is a major shift in international taxation. It is not intended to replace other methods of exchange of information, but be applied in parallel and address some flaws. Organization for Economic Cooperation and Development (OECD) along with G20 countries was responsible for the development of this new single standard, which is a framework for automatic exchange of financial information. The purpose of the new Standard is to promote cooperation among various jurisdictions to automatically exchange information from their financial institutions with other jurisdictions on an annual basis. It addresses a long-endured problem in international taxation - offshore tax evasion (Urinov, 2015). On the other hand, sustains better tax law enforcement on the foreign-source income of residents.

The global Standard comprises of the Competent Authority Agreement (CAA) and Common Reporting Standard (CRS). In the CAA, detailed rules on the exchange of the reported information between countries are specified, i.e., rules on confidentiality, safeguards and the existence of the necessary infrastructure for an effective exchange system. CRS contains the reporting and due diligence rules to be imposed on financial institutions. The financial account information to be exchanged is set, along with reporting financial institutions, different types of accounts and taxpayers covered, followed common due diligence procedures. Financial institutions covered by the Standard include custodial institutions, depositary institutions, investment entities and specified insurance companies. Financial institutions send this information to their own competent authorities (in country 1), who will then exchange the information with the corresponding authorities (located in countries 2, 3 and 4). For reciprocity purposes (the default option so far), financial institutions located in countries 2, 3 and 4 would also collect information on residents of countries $1,2,3$ and 4 and send it to their own competent authorities so that they exchange it with the corresponding authorities.

Major moment for the international legal framework was the signing of the CRS Multilateral Competent Authority Agreement (CRS MCAA) in October 2014, where 51 jurisdictions signed the MCAA to automatically exchange information under the Standard. MCAA is one of the very few multilateral agreements that exist in the field of taxation, apart from the fact that major developed countries (the United States of America, Canada, Japan) did not sign the agreement. For developing countries, MCAA has been signed by a few ones, while the number of committed signatories for September 2018 is growing (OECD, MCAA, 2016).

The exchanged information includes the name of the taxpayer, tax identification number (TIN) assigned by the residence country, the taxpayer's temporary and permanent addresses, the type and the amount of income earned for the period, and the details of the payer in the source country. Additionally, other items such as information on financial assets, immovable property, value added tax refund, etc., might be covered (OECD, 2012, p. 7).

Although it is difficult to measure all material effects, automatic exchange encourages resident taxpayers to accurately report to their countries of residence income, stemming from foreign sources. On the other hand, automatic exchange of tax information provides equal treatment of the resident taxpayers, no matter the source of income (domestic and foreign). Hence, limiting the opportunity for tax-distorted reallocation of economic and financial resources offshore (Urinov, 2015).

It is worth mentioning that the new OECD Standard is a culmination of earlier OECD's work in the area of automatic exchange of information (OECD, 2016). On the other hand, it leverages on progress made within the European Union, as well as global anti-money laundering standards, with the intergovernmental implementation of the US Foreign Account Tax Compliance Act (FATCA). As summarized by some researchers (Knobel \& Meinzer, 2014; Urinov, 2015) and having reviewed the participating jurisdictions, the global Standard is predominantly intended for developed countries and tax havens. 
In 2010, the United States enacted legislation commonly referred to as FATCA, which effectively requires foreign financial institutions around the globe to report account details of their U.S. customers to the U.S. tax administration.

For EU Member States, CRS is transposed by the amended EU Directive on Administrative Cooperation (DAC2).

Council Directive 2014/107/EU on administrative cooperation in direct taxation (,DAC2 ${ }^{\prime}$ ), which pror vides for mandatory automatic exchange of financial information, was adopted in 2014. DAC2 amends the previous Directive on administrative cooperation in direct taxation, Directive 2011/16/EU (,DACl'). The European Directive 2011/16/EU concerning tax administrative cooperation came into force on January 1, 2013. DAC2 become effective as of $1^{\text {st }}$ of January 2016 with a view of performing the first exchange of information between tax authorities in 2017. The said Directive brings interests, dividends, as well as account balances and sales proceeds from financial assets within the scope of the automatic exchange of information.

\section{AUTOMATIC EXCHANGE OF INFORMATION}

\subsection{Global and EU approach}

Automatic exchange of information means the systematic and regualr transmission of "bulk" taxpayer information by the source country to the residence country concerning various categories of income (e.g., dividends, interest, etc.) (EC, 2015).

Automatic exchange of information (AEoI) forces the financial institutions in which bank accounts was opened by non-residents (including through intermediary structures) to provide to tax authorities as per FATCA or CRS specifications not only information concerning all kinds of investment income (interests, dividends, income of life insurance agreements and other similar income), but also the balances and the income of financial asset's sales. Tax authorities receive the information, validate it and are responsible for transfering the information to the partnering tax authority.

FATCA is much narrower in scope than the CRS, and only focuses on certain U.S. persons. Differences between FATCA and the CRS mean that enhancement by financial institutions might not be applicable for both standards in respect of due diligence and reporting systems (KPMG, 2015). Both treaties introduce a great number of specific definitions, which are used for the implementation of the AEoI, as some of the terms are not corresponding (Arkiomaa, 2016). Finally, key difference is the extent of reciprocity in the automatic exchange of financial account information between FATCA and the CRS. FATCA is not truly reciprocal, while CRS is truly reciprocal. As concluded by Arkiomaa (2016), CRS lacks efficient compliance incentives and enforcement of sanctions as opposed to FATCA. In summary, divergence leads to implementation, cost and system design issues for many jurisdictions.

At the EU level, tax matters and tax evasion are also actively addressed throughout the last years. Several legal initiatives were introduced - Savings Directive (2005) and the Directive on Administrative Cooperation, Directive 2011/16/ EU (DAC1). In 2012, the European Commission presented an action plan to strengthen fight against tax evasion. This plan highlights the need to promote AEoI as the European and international Standard for tax matters. This Directive requires from 2015 automatic exchange of information between member states on five categories of income and capital: employment, directors' fees, life insurance products not covered by other directives, pensions and ownership of and income from immovable property.

In 2014, DAC1 is modified by the Directive 2014/107/ EU (DAC2) which had extended the cooperation between tax authorities to the automatic exchange of information on financial accounts. In fact, in order to set up a common procedure of automatic 
exchange within the EU, the Commission had chosen to take up the Common Standard of OECD in the 2014 Directive (amending the Directive on Administrative co-operation dated 2011, “DAC").

In respect of Multilateral Competent Authority Agreement (MCAA) to the OECD's Common Reporting Standard (CRS), all the EU member states have signed it, which means full reciprocig ty from all jurisdictions. There is a commitment to start exchanging information in 2017.

Things are additionally complicating with the adoption of revised EU Savings Directive (EUSD). Financial institutions in a country under the scope of EUSD that also adopts CRS will have to comply with the reporting requirements, unless the latter conforms to the CRS at a later stage.

EU member states are also considering changes to the Administrative Cooperation Directive, which provides for reporting that is similar to the CRS. DAC3 builds upon DAC2 by including information exchange on tax rulings At this point it is unclear whether reporting under the Administrative Cooperation Directive will converge with the CRS.

\subsection{Bulgarian approach for automatic exchange}

Bulgaria is an EU member-state and has transposed Council Directive 2014/107/EU of December 9, 2014 amending Directive 2011/16/ EU with regard to mandatory automatic exchange of information in the field of taxation. Along with this, Agreement between the Government of the United States of America and the Government of the Republic of Bulgaria to Improve International Tax Compliance and to Implement FATCA is signed on December 5, 2014 in Sofia, ratified with an act (SG, issue 47 of 2015).

As of January 1, 2016, Bulgaria has implemented the rules on automatic exchange of financial information in compliance with the European Union (EU) legal framework, OECD recommendations, and FATCA. Tax and Social Security
Proceedings Code (TSSPC) is amended with the inclusion of new provisions and administrative procedures regarding the automatic exchange of financial information in the field of taxation. Certain provisions regulate the realization of the administrative cooperation by means of the automatic exchange of financial information in the field of the taxation with participating jurisdictions, the obligations of the financial institutions providing information, the applicable procedures for complex check and the provision of financial information.

Hence, TSSPC introduces the provisions of Council Directive 2014/107/EU, as well as provisions in compliance with the application of the FATCA and OECD CRS in the national law.

Along with this, Bulgaria has joined other international initiatives developed by OECD on tackling tax evasion through an automatic exchange of information for tax purposes - Convention on Mutual Administrative Assistance in Tax Matters, the Multilateral Agreement between the Competent Authorities on the Automatic Exchange of Financial Account Information and the Global Forum on Transparency and Exchange of Information. The Convention and MCAA entered into force on July 1, 2016, thus providing a multilateral tool which will allow a broad range of countries to take advantage of tax cooperation.

All the above stated means that every year, starting from 2017, the Bulgarian tax authority will be able to get information about the assets owned by Bulgarian residents (incl. also structures like trusts or foundations) in a financial institution located in a country having signed an automatic exchange convention. For some major jurisdictions, incl. USA, the process is not reciprocical as bilateral agreements should be signed in order to obtain financial information.

\subsection{Bulgarian banks in light of automatic exchange}

Bulgarian banking system is subject to the legislative framework introduced by the CRR/ CRD IV package. Capital Requirements 
Regulation (Regulation (EU) № 575/2013) is directly applicable in Bulgaria as the EU member state, while the fourth Capital Requirements Directive (Directive 2013/36/EC) is transposed into national legislation by the Law on Credit Institutions (LCI). Regulation and supervision of Bulgarian credit institutions is conducted by Bulgarian National Bank (BNB).

The number of banks operating on the Bulgarian market is 28 ( 22 banks licensed by the BNB, plus 6 foreign bank branches operating in Bulgaria). As of June 30,2016, total assets of Bulgarian banking system stand at EUR 45.3 billion, 5.7\% yearly growth.

The introduction of automatic exchange of financial information with relevant foreign jurisdictions requires the application of due diligence procedures, control of financial accounts and collection of information with specific details and elements from clients upon opening an account in every Bulgarian bank.

As mentioned and in accordance with Tax and Social Security Proceedings Code, every ree porting financial institution collects tax purposes information from its clients for state/ states. A self-certification is provided with tax identification number and relevant data. Additional information, self-certifications and/ or documentary evidence may be required by account holders of existing accounts.

After identifying the client, banks should submit information on a standard form to the National Revenue Agency (NRA) on an annual basis. NRA is the responsible body for the collection and administering of Bulgarian state taxes (income tax, patent taxes, VAT, corporate taxes). In respect of automatic exchange of financial ini formation with the competent authority of each participating jurisdiction, NRA is the compes tent Bulgarian body.

Having said that, NRA has provided guidelines, applications and forms in respect of automatic exchange of financial information.

Complicated regulatory requirements are challenging financial institutions as proved by
FATCA (EC, 2015). Financial institutions need a lead time of at least 18 months in advance of the effective date, starting from the time the final guidance has been released. In respect of the entry into force of the DAC2 provisions in EU member states, testing or reporting mechanisms with the respective domestic authorities is scheduled for Q2 2016 in order to allow for effective final transfer of data from financial institutions to local tax administration (NRA for Bulgaria) in early to mid-2017.

\section{RESEARCH}

On first part of the research, literature related to automatic exchange of information (AEoI) and automatic exchange of tax information (AETI) is examined. This involves global initiatives undertaken, EU approach, both historical and as an ongoing and approach.

There is a very limited number of articles, research papers on automatic exchange of tax information (AETI), its initiation and/or implementation, prepared by Bulgarian researchers. Hence, this paper sheds some light in respect of initiation, implementation, and responsible bodies.

In order to investigate the automatic exchange of tax information (AETI) in Bulgarian context, major sources include:

- for historic development - website of National Revenue Agency, section automatic exchange of financial information; data by Deloitte Bulgaria and KPMG Bulgaria;

- for legal framework - website of National Revenue Agency, Bulgarian Parliament, with respect of applicable legal acts and documents concerning the automatic exchange of financial information under the FATCA IGA, the OECD CRS and Council Directive 2014/107/EU, OECD, CRS implementation and assistance, CRS by jurisdiction;

- for responsible and competent authorities - website of National Revenue Agency, Bulgarian Parliament; 
- for application of DAC2 and expectations for newly approved DAC3 - no Bulgarian researches, European Commission Expert Group on Automatic Exchange of Financial Account Information, OECD, CRS Implementation and Assistance, CRS by jurisdiction.

In the study, Bulgarian financial institutions (banks) are examined, implementation status and how the challenge of AETI, including client information and data protection are addressed.

Primary data for banks are collected from publicly available sources (website of the respective bank), as company websites of top 5 Bulgarian banks were examined for information related to automatic exchange of financial information/tax information. Sample size comprises of the five largest banks based on the amount of their assets as of June 30, 2016 (BNB, 2016): Unicredit Bulbank, DSK Bank, FIBank, United Bulgarian Bank and Eurobank Bulgaria. Data are collected in July and early August 2016.

\section{RESULTS}

Results show that major Bulgarian banks, within First Group in terms of assets, are initiating the process of automatic exchange of financial information. In terms of total assets, five largest banks have grown year on year from EUR 23.7 billion to EUR 26.1 billion with total share within banking system $57.6 \%$ vs. $55.3 \%$ a year earlier.

Largest Bulgarian bank with EUR 5.9 billion assets as of June 30, 2016 is Unicredit Bulbank. Bank was established in 1964 and is part of Unicredit Group. Among business lines, Bulbank is a leading player on retail banking market, corporate banking, state and municipalities, among others.

DSK Bank was established in 1951 as a state savings institution. The bank is a part of the Hungarian OTP Group. DSK Bank has never lost its leading retail banking position, as currently is an undisputed leader in retail banking. Corporate banking is also growing and becoming competitive business line. DSK Bank is number two with EUR 5.9 billion assets as of June 30, 2016.
First Investment Bank (FIBank) is the largest bank with Bulgarian shareholders (EUR 4.4 billion assets as of June 30,2016). Bank was established in 1993, with strong focus on customer service and substantial presence on retail banking and corporate banking markets.

United Bulgarian Bank (UBB) is established in 1992 and is part of the financial group of the National Bank of Greece. UBB is an universal bank with well-developed retail and corporate banking. UBB is number four in terms of assets with EUR 5.9 billion as of June 30, 2016.United Bulgarian Bank is a part of the financial group of the National Bank of Greece.

Postbank, legally named Eurobank Bulgaria AD, is the fifth largest bank in Bulgaria in terms of assets (EUR 3.4 billion assets as of June 30, 2016). Eurobank Bulgaria is a part of Eurobank Group and is established in 1991. Bank possesses a broad branch network and a considerable client base of individuals, companies and institutions.

Information in respect of FATCA and/or CRS is provided on corporate websites, including brief introduction, obligations, etc. There is no specific standard and format requirement, as some of the examined banks are providing extended information. Bulbank, for example, has special section, titled FATCA, where GIIN number, certificates are attached, along with registration in Internal Revenue Service portal as "Registered Deemed-Compliant Financial Institution". Internal due diligence is launched and preparation for the new reporting requirements. DSK Bank is also providing some initial information.

General conclusion is that, currently there are some critical issues to be addressed and tight deadlines to be followed. Differences between FATCA and OECD CRS do not allow enhancement in order both standards to be applicable for due diligence and reporting systems. Hence, additional costs and time spent for development and implementation. Additionally, new DAC3 might also introduce higher challenges. For sure, practical guidance are the solution, publication of a FAQ on some specific topics by NRA, along with strong commitment by all stakeholders. 


\section{CONCLUSION}

Throughout the last years, tax evasion via cross-border tax avoidance and tax fraud is increasing. Tax havens enable financial crimes (money laundering, finance of terrorism, hiding proceeds of corruption, evading taxes, market rigging, etc.) by offering secrecy to individuals and companies. This poses great challenge for countries (both within the European Union and worldwide). Authorities worldwide have intensified their focus on efficiency and effectiveness of tax collection and on implementing global approach for tax evasion. The automatic exchange of information (AEoI) is an important tool for increasing the effectiveness of tax collection and control on cross-border cases of tax fraud and tax evasion. In February 2014, the G20 Finance Ministers endorsed the OECD proposal for a Common Reporting Standard (CRS), making global automatic exchange of tax information working. Up until 2014, the main global standard to exchange information among tax authorities was upon request.

In respect of Bulgarian and role of stakeholders, it is worth mentioning the role of Bulgarian lawmakers, authorities and representatives in various EU bodies. Evidence proves that involvement in the discussion, crafting and introduction of new legislation on EU level is relatively limited, compared to other member states. The interest of local financial institutions and banks in particular is not well addressed. Usual approach is transposition of EU Directives, without estimating the costs, effects and timeframe. For automatic exchange of information issues, including FATCA, there is no in-depth analysis, research or survey on the implementation, effects, costs.

Bulgarian banks are initiating the process of automatic exchange of financial information. All instructions coming from National Revenue Agency and stemming from agreements are strictly followed. Major critical issues are addressed internally, as additional costs are expected and extra time for development and implementation.

It is foreseen, AEoI pursuant to the CRS to become effective in 2017 or 2018. In this respect, participats ing jurisdictions (101 as of May 2016) will exchange data. CRS is a substantial step in the coordinated approach to disclosure of income earned by individuals and entities. Still, in order to become global, integration of developing countries, taking into consideration their constraints, is crucial.

For now, it's difficult to draw up an overview of the practical implementation of the new global and EU initiatives, concerning automatic exchange of financial information for tax purposes and the amount of transferred information and the efficiency of this legislation. By all means, the commitment and new initiatives guarantee a breakthrough in cross-border tax evasion and tax fraud.

The paper has some limitations, related to automatic exchange of tax information in respect of global initiatives only. Limitations are related to the country examined - Bulgaria; financial institutions banks only; sample size - only five largest Bulgarian banks are included in the research.

Further research could try to shed light on other Bulgarian banks, outside of top 5, their status in respect of automatic exchange of tax information.

\section{REFERENCES}

1. Arkiomaa, M. (2016). The

Differences in the Automatic

Exchange of Financial Account

Information in Tax Matters between FATCA and CRS.
2. Bulgarian National Bank, Bank Supervision, Credit Institutions (Banking Sector). (2016). Retrieved from http://bnb.bg/bnbweb/groups/ public/documents/bnb_download/ bs_201606_a0_en.pdf
3. Council Directive $2003 / 48 /$ EC of 3 June 2003 on taxation of savings income in the form of interest payments.

4. Council Directive 2011/16/EU of 15 February 2011 on administrative 
cooperation in the field of taxation and repealing Directive 77/799/ EEC.

5. Council Directive 2014/107/EU of 9 December 2014 amending Directive 2011/16/EU as regards mandatory automatic exchange of information in the field of taxation.

6. Deloitte Bulgaria, Tax Newsletter (2015). Retrieved from https:// www2.deloitte.com/content/ dam/Deloitte/bg/Documents/tax/ Tax\%20Newsletters/tax_newsletter2016_bg.pdf

7. DSK BANK (July 27, 2016). Retrieved from https://dskbank.bg/ repository/documents/Uvedomlenie_personal_data_19072016.pdf?

8. DSK BANK (July 27, 2016). Retrieved from https://dskbank.bg/ Page/default.aspx?xml_id=/bg-BG/ About/.FATCA/

9. DSK BANK (July 27, 2016). Retrieved from https://dskbank. bg/repository/documents/OU_accounts_25042016.pdf?

10. DSK BANK (July 27, 2016). Retrieved from https://dskbank. bg/repository/documents/OU_ business_clients_11012016.pdf?

11. Europen Commission, New framework in the EU for Administrative Cooperation (August 22, 2016). Retrieved from http://ec.europa.eu/taxation_customs/resources/documents/taxation/tax_cooperation/mutual_assistance/direct_tax_directive/ administrative_coop.pdf

12. European Commission, Directorate-General for Taxation and Customs Union (2015) Implementation of Directive 2014/107/EU - automatic exchange of financial account information First Report of the Commission AEFI expert group on the implementation of Directive 2014/107/EU for automatic exchange of financial account information FIBank. (2016). Retrieved from http:// fibank.bg/uploads/_BankAccounts/docs/GTC_BankAccounts. pdf

13. Knobel, A., \& Meinzer, M. (2014). Automatic Exchange of Information: An Opportunity for Developing Countries to Tackle Tax Evasion and Corruption. Tax Justice Network.

14. Knobel, A., Olier, C., Giegold, S., Meinzer, M. (2016). The Role of the U.S. as a Tax Haven Implications for Europe, A Study Commissioned by the Greens/ EFA Group in the European Parliament.

15. KPMG, Automatic Exchange of Information, The Common Reporting Standard, How financial institutions can adapt to new global standards. (2015). Retrieved from https://www. kpmg.com/Global/en/IssuesAndInsights/ArticlesPublications/ frontiers-in-tax/Documents/thecommon-reporting-standard.pdf

16. KPMG Bulgaria, Tax Analysis, Retrieved from https://www.kpmg. com/BG/en/IssuesAndInsights/ ArticlesPublications/Tax-Analyses/ Documents/2015-02-Tax-Analysis. htm (accessed on July 25, 2016).

17. National Revenue Agency. (2016). Retrieved from http://www.nap. bg/en/page $? \mathrm{id}=581$

18. National Revenue Agency, Automatic exchange of financial information. (August 6, 2016). Retrieved from http://www.nap. bg/en/page?id=581

19. Organisation for Economic Co-Operation and Development
(OECD) Common Reporting Standard (CRS). (2016). Retrieved from https://www.oecd.org/ctp/ exchange-of-tax-information/ automatic-exchange-financialaccount-information-commonreporting-standard.pdf

20. Organisation for Economic Co-Operation and Development 2012: Automatic Exchange of Information. What it is, How it Works, Benefits, What Remains to be Done, Paris. (2016). Retrieved from http://www.oecd.org/ctp/ exchange-of-taxinformation/ AEOI_FINAL_with\%20cover_ WEB.pdf

21. Organisation for Economic Co-Operation and Development (OECD) Common Reporting Standard (CRS). (2016). Retrieved from https://www.oecd.org/ctp/ exchange-of-tax-information/ MCAA-Signatories.pdf

22. Postbank. (2016). Retrieved from https://www.postbank.bg/repository/files/SBB/GTC/20160407_ GTC\%20Accounts\%20Juridical_3003.pdf

23. Tax-Insurance Procedure Code, amend. SG. 94/ 04 Dec. 2015, in force as of January 1, 2016

24. UBB (2016). Retrieved from https://www.ubb.bg/attachments/ Term/43/main_bul/Obshti-uslovija-za-platejni-uslugi-individualniklienti-02112015.PDF

25. UBB (2016). Retrieved from https://www.ubb.bg/attachments/ Term/44/main_bul/Obshtiuslovija-za-platejni-uslugi-biznesklienti-02112015.pdf

26. Urinov, V. (2015). Developing Country Perspectives on Automatic Exchange of Tax Information. Law, Social Justice \& Global Development Journal, 1. 